\title{
THE FANTI FAMILY SYSTEM
}

A CONSIDERABLE amount of difficulty arises at the outset of this subject, owing to a confusion of the terms used by Europeans on the West Coast of Africa, to describe the various relations amongst the natives, and I think it only right to preface this article with a few definitions which, although perhaps not legally exact, will help to make my meaning more clear in distinguishing between "tribe," " sept," "clan," and "family."

By a "tribe" I mean the Fanti term "Oman" (pl. "Aman "), which denotes all those persons who form a political community, with a more or less definite area, under one omanhin, who is supreme, these persons speaking the same dialect, and being subject to the same customs.

Thus, in the Gold Coast Colony itself, the Twi-speaking tribes may be divided into:-

(a) Those who speak the Akan dialect of Twi:-viz. in Assini, Amanahia (Apollonia), Awini, Ahanta, Wassaw, Twiforo (Mampong), Denkera, Assin, Akim Kotoku (Western Akim), Akim Abuakwa (Eastern Akim), Akwapem, Akwamu, and Kamana.

(b) Those who speak the Fanti dialect of Tw̌i :-viz. in Abra (Abrakrampa), Kommenda, Elmina, Effutu (including Cape Coast or Egua), Mankessim (Fanti proper), Ajimako, Akomfi, Gomoa, Agona (Nsaba), and Agona (Essikuma).

By a "sept" I mean all those persons who claim their descent from a common female ancestor, on analogy to the tribes of Israel, with this important distinction, that each Coast tribe has its own particular ancestor, and these ancestors do not appear to have been in any way connected with one another. 
By a "clan" I mean what I have elsewhere called a company, viz. all those who form a village community, under their own chief or headman, to whom they owe direct allegiance, the chief being subject to the Omanhin.

By "family" I mean the immediate blood-relations in a particular tribe, traced through the eldest surviving female, and only in the female line.

It is unfortunate that the natives use the same term " Ebussia" (nasal "a") for both the sept and the family, which is very misleading to a European, as the same septs (or totemkins) are found throughout all the tribes, not only in the Gold Coast, but also in Ashanti, all of whom are connected, and yet the tribes themselves are distinct. I have therefore considered it necessary to use separate terms which otherwise might appear superfluous.

Without further apology I will now point out, what I hope will appear clear, that the tribes and clans are political divisions on the Coast, while the sept (including the family) is purely domestic, and it is the latter only that $I$ now intend to describe.

From all I can gather, the whole of the Gold Coast Twispeaking tribes, and Ashanti, recognise seven principal septs (or totem-kins), viz.:-(I) Nsonna, or fox (bush-cat); (2) Annona, or parrot; (3) Twidan, or leopard (Fanti " etwi "); (4) Kwonna, or buffalo (F. " eko "); (5) Abradzi, or plantain; (6) Ntwa, or dog; (7) Adwinadzi, or silurus. ${ }^{1}$

Each of these has its branch or branches, and in some races the branch is looked upon as the principal, so that it might be interesting to compare those of Cape Coast Castle (C.C.C.) with Denkera (D.) and Fanti Yankumase (F.Y.), thus :-

(I) The Nsonna remains the principal in all three places (in the D. and F.Y. dialects it is "Asona"), with a branch at C.C.C. called Dwimina (after a plant).

(2) The Annona has its branches at C.C.C., Yoko (a red ochrous earth), (D. Ayuku, F.Y. Oyoko), and Agona (palm oil). In this case, Fanti Yankumase recognises all, but considers Oyoko the leading tribe, and has a further branch, Osansa (kite or hawk), whereas in Denkera the Agona

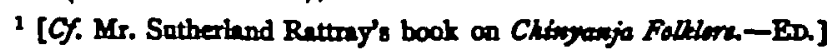


is the important one, as being that to which the Omanhin belongs.

(3) The Twidan is known to F.Y., but not to D., although the Denkeras have a tribe known as Abretin, which I cannot trace elsewhere, so it may represent this one. At C.C.C. this sept has a branch Eburutu (corn-stalk).

(4) The Kwonna is the principal in C.C.C. and F.Y., and has its branches at C.C.C., Ebiradzi, and Odumna; in D. it is superseded by the Ahuini. In C.C.C. a branch is also known as Dihyina (the name of a fetich meaning "scarcity of blood").

(5) The Abradzi is known in C.C.C. and D., but does not seem to be known by that name in F.Y., where it is probably represented by the Assinye sept to which the F.Y. Omanhin belongs (from "Assinoa," a bird that frequents the silk cotton tree); D. also has a branch of this name, so $I$ include it here as well, while at C.C.C. a true branch is the Ofurna.

(6) The Ntw̌a is a leader in C.C.C., and D. (D. Achwia), having branches in C.C.C., Abadzi, and Appiadzi (a servant), while in D. a branch is the Aduana. In F.Y. the Abadzi only exists.

(7) The Adwinadzi sept of C.C.C. has a branch Aowin (which means from the Ahunta Coast). This name does not occur among the septs of D. or F.Y., and although I have not been able to connect them $m_{2}$ it appears to represent the 7 th sept, which in both D. and F.Y. is known as Asachiri (a vulture).

Cape Coast Castle has been the most important town on the Coast for some centuries, hence it is that all the above septs are there well represented.

The members of each sept are very loyal to each other, to whatever tribe they may belong; so, whenever a member of a sept dies, all the members of that sept are liable to share the funeral expenses, although it is now the established custom for only the immediate relatives ("family") to share them, accepting any donations that the others may choose to contribute; but cases still occur where the "sept," as distinguished from the "family," bears such expenses, as when an Nsonna man of Akwapem (say) comes to Axim and dies 
there, having no relatives with him, all the Nsonna members in Axim bury him and share the expenses, Akwapem being too far to inform his family, who would otherwise perform the custom. It is chiefly for this purpose that whenever a stranger comes to a place, he invariably makes himself known by the name of his sept, and he is at once accepted by the members of that sept as though he had been born amongst them, yet he may belong to a tribe whose name is scarcely known there.

Each sept accounts for its origin by some tradition; thus the Omanhin of Denkera, Nkwanta Bissa, who lives in the Cape Coast District, at Jukwa, is a member of the Agona, or parrot tribe. He told me that " his original ancestor was a woman who went to some far distant country, and was there married. She quarrelled with her husband, and left for her country, and on the way home she met a murderer, who was about to assault her, but following native fashion, he first asked her with whom she was walking ; she boldly replied, her people were coming behind. He asked who they were, and how many; she shouted, and a parrot that was approaching answered, 'Ohor !' The man, thinking somebody was coming, of a truth, ran away, leaving the woman to continue on her road. After some time she returned and brought back her children from the far country, and this family originated the Agona tribe, which in time increased, and multiplied, and spread all over Assin, Ashanti, Fanti, and other countries; and all Agonas are consequently descended from that woman, and all Agonas revere the parrot whose ancestor saved their ancestor from disgrace and even death." 1

I have given this tradition as nearly as possible in the chief's words as they were interpreted, and I regret to say a strange incident prevented my learning the origin of at least some other septs. The Omanhin had told me his own totem, after much hesitation, when I was one day discussing the Denkera customs before a meeting of his councillors. Several of his important chiefs were present, who had come in to

\footnotetext{
' [In the Journal for October, 1905, appears the tradition of the Safwo Nanadem or "Bonito" ept at Chame. This may posibly be bdentical with the Adrrinidri or "Siluras."-ED.]
} 
attend his "Yam Custom," and each promised to relate his own story after the Omanhin had finished; when the Omanhin had done, they had some scruples, so the Omanhin retired to consult his fetich, whether he had done wisely or not. On his return, they all made some excuse, which the interpreter would not interpret; this rather annoyed me, and I expressed my dissatisfaction, but instead of telling them what my feelings were, he gave a shout, threw up his arms, went rigid, foaming at the mouth, and fell to the ground in an epileptic fit. No one stirred a hand on his behalf, although he was the chief's own clerk, and I was left to bring him to by myself. This settled the question of origins, as they all attributed the fit to the anger of the fetich, so after laying the clerk on a couch, I did not press the subject any further, but continued the palaver on other customs, falling back on my cook as interpreter. The clerk was a well-read man, and of middle age, and I attribute the incident to the fact that he was in a dilemma, as I afterwards learned that they had all laid a curse on him if he referred to the subject again, and his nerves must have got the better of him when he saw I was offended at his apparent contumacy. (A similar fit seized another interpreter, when $I$ was once investigating a rather important fetich case, at Anum in the Krepi country, and I could not get a substitute in a crowded court, until I convinced them that the fetich had made a mistake in seizing on the wrong person, as the result depended entirely on me; I finally challenged the witness, who was the chief fetich priest in the place, to try his charms on myself, as I intended to finish the case at all costs. This brought forward one man who was a bit bolder than the rest, and I ate only tinned food that day-as poisons are wont to do what fetiches cannot !)

It will be noticed that the septs are all named after some animal or plant, and there appears to be much doubt whether these different tribes hold their namesakes in veneration only, or worship them as gods. As a matter of fact, they certainly do not worship them, as a Twidan does not hesitate to shoot a leopard if it eats his sheep, nor does an Abradzi mutter a prayer when he eats a plantain, which is one of the staple 
foods of the Coast. ${ }^{2}$ They merely take the name from some such myth as I have detailed, and the fetich at Jukwa appeared to have been angry only because the Omanhin had discussed his ancestors, which is a sacred topic.

A fetich is another matter altogether, which is little understood, and I reserve the subject for another chapter.

Each family includes members on the mother's side only; thus the mother, and all her children, male and female, belong to her family; so do her mother and maternal uncles and aunts; but her father and all his relatives are nothing at all to her, nor are her husband nor any of his relatives; her daughters' children, male and female, are members of her family, but her son's children are not, as they belong to the family of the son's wife, marriages in the family being prohibited; marriages even in the same sept, although they do sometimes occur, are not countenanced. The eldest living maternal ancestor is the head of the family, so that it will easily be seen that the family must sooner or later branch, just as they do in our own system, and although they are at first easily traceable, they soon become recognisable only by bearing the same common name, for every child bears the family name of the mother as a cognomen, in addition to one given to it at its birth by the father, while the first name is invariably taken from the day of the week on which it was born. This branching of a family in the same tribe (for inter-tribal marriages were practically unknown) will, I hope, clearly justify my use of the term family, as distinct from the far wider term sept, although the native use of the same term "ebussian" for both is, from their point of view, quite logical, as when one branch becomes extinct, the surviving branch remains the heir-at-law.

I have mentioned that the eldest member of the family is recognised as the head, but where this member is a woman, and more particularly where the family is connected with a stool, the head delegates her authority to her eldest son, or the eldest male in the family. Women have, however, been

1 [Does not this show that the institution is becoming obsolete and the traditions falling into oblivion?-The Achewh, mps Mr. Rattray, never eat or make use in any way of their totem animal or plant. - ED.] 
known to occupy the stool as reigning chiefs. Adoption proper is unknown, but if a distressed native commends himself to a family, and they approve, he is received by them as a domestic slave, and, as such, becomes absorbed into it. Again, in Fanti Yankumase, for instance, if a member of another tribe settles with them, and his sept, the Kwonna (say) will not help him, he may choose one of the others, who will, and he henceforth is treated as a member of the latter.

There seems to be some doubt as to the difference in the status of a woman's child, according as the woman is a wife or a concubine. There is no doubt whatever that in the case of a wife, the children belong to her family alone in Fanti countries; the father has only a life-interest in them; he pays for their keep, feeds, and educates them; he sets them up at the outset of their career with money or other means of obtaining a living, and until they start life for themselves he is entitled to whatever profits they make; he also pays any fines that may be inflicted on them by the chief, and "satisfies" individuals who make a claim against any of them; he may also chastise them, but he may not sell or pawn his own children. Unless a man fulfils all these conditions, his children can refuse to provide his coffin and burial cloths at his death; and this is considered the height of disgrace by the native, as in that case his family provide the coffin in addition to all the other expenses involved.

In the case of a concubine, the matter is a little more complicated, for a woman may live with one man as his concubine, which is not generally considered a dishonourable condition; but it is usual, in such a case, for the parents to press for a completion of the formal marriage as soon as the woman becomes pregnant; then the child is born in wedlock.

If the marriage is not pressed, the man may pay all the confinement expenses and the keep of the child until it is weaned, and he can then claim the custody till his decease; the child, nevertheless, still belongs to the woman's family, and buries the father as before.

But where the intercourse had been promiscuous, or, owing to the easy virtue of the woman, the man refuses to own the 
offspring, then the woman's family assume sole control, and the child has no call on, or obligation to bury, the man.

If the father claims the child, but the woman's family insist on keeping it, the father may say, " All right, I am 'dead,' then bury me." This means the family have to pay him whatever amount is estimated it would cost to bury him, to wipe out the future disgrace of this child not participating in his funeral.

If the woman, not being married, formally married some other man, two courses are open :- $(a)$ the natural father invariably claims the child, and takes possession ; $(b)$ otherwise, and in cases where the natural father is unknown, the woman keeps possession, and her husband looks after it as though it were his own.

The husband also looks after all children by a former husband, if his wife had been a widow, and if they are too young to earn their own living; all such previously begotten children are termed "Abanoma."

With reference to widowhood and divorce further details will be given under the title of "Marriage," but the invariable rule, in Thi-speaking races, is that the child belongs to the family of the mother, but has the right to live in the father's house, even after his death, during good behaviour.

There were three distinct classes of bondage on the Gold Coast and Ashanti, which I will distinguish by the names :Foreign slaves, Household slaves, and Domestic slaves.

(I) Foreign slaves included (a) all captured in war and in raids on neighbouring tribes (numu); these were always numerous, as perpetual attacks were made on all sides, and the Ashantis continually ravaged all the Coast tribes. There were also (b) those who were sent by tributary tribes to their paramount chief (akwa or ahoho). And during the worst phase of the slave trade (c) families sold their own children into foreign slavery, without any hope of redemption, for pure gain (nyafo). War captives were almost invariably kept for sacrificial purposes, although sometimes exchanged. The same fate awaited a good many of those who were sent as tribute, when war slaves were scarce; but usually they were bartered or sold. Both these forms be- 
longed to the "stool," and were used only for State purposes. When children were sold into slavery it was usually by private treaty; they were used to till the soil for their masters, or sold by them, at a profit, to regular slave dealers.

(2) Household slaves (otutunafo) I term all those who were unable to repay some great service rendered to themselves or to their families, and who gave themselves up to, or were seized by, their benefactor (odefu), serving him as a retinue, and sometimes as a personal bodyguard; these were not transferable, being free-born, and fellow-countrymen. Their relations were personal, and continued as long as the obligation lasted. If it had not ceased at the owner's death, the heir inherited them with the property. They could not be given away or sold.

(3) Domestic slaves were those who, owing to poverty, or dangerous surroundings, were compelled to bind themselves alone, or with their whole family, to serve a wealthy or powerful neighbour, who accepted their services either for a lump sum to clear the debt, or merely in exchange for the bare necessaries of life. They were always freemen ("Dihi ") and countrymen of their master, and formed part of his family, but did all the menial work of the house and in the field. Their lot was not a very hard one, as they were generally well treated, and a good many were allowed to work for themselves and keep what they made, and even could own slaves themselves (I find this was the case in Fanti Yankumase); but in all my enquiries I have invariably been told that in no circumstances could they obtain their freedom, although Mr. Sarbah, in his Fanti Customary Laws, cites a case in 1871 where two native chiefs, as judicial assessors, advise the court that slaves can be freed (pp. 8-9). It is certainly not admitted by tradition.

As husband and wife can own property separately, so the slaves might belong to the master or to the mistress, and this point becomes important, with reference to the children of the slaves, who remained slaves, and belonged to the family of their owner. Their marriage, when contracted with free persons, will be dealt with under Marriage Customs.

No form of clientship exists, but slaves look upon the head of the family in the same way as any other member would, 
so that very few domestic slaves have any reason to want to free themselves, and would not know what to do with themselves if they were free; practically all of them, having now been born to look upon themselves as unpaid servants, are quite content to do the little services that are required of them for the sake of their food.

Being considered members of the family, it is not at all unusual to see a slave inheriting property, if there are no heirs; or acting for very young children; but this will be referred to under Inheritance.

The first two forms of slavery have now practically disappeared, under heavy penalties, although the Hausa traders still contravene the law, and bring down quite young children from the Fra-Fra and other distant inland countries; and some wealthy and philanthropic Fantis pay fair prices for them, "to save them from a worse fate"l Their philanthropy only extends so far as the "better" fate is to become the domestic slaves of their new master. These domestic slaves are tolerated by us, inasmuch as they form part of the native family institution, and as things go they are quite content to be what they are, and only attach themselves to someone else in the few cases where they run away and claim protection from District Commissioners. Slaves were formerly made to "drink medicine" when first enslaved, and were made to believe it would kill them if they attempted to run away; they sometimes did run away, and were as often caught, without the decoction having had its threatened effect; to intimidate them more, they were then given a larger dose, and to impress it on them an ear or a nose was cut off ; if this did not deter them, they were either killed or sold as absolutely hopeless.

There is one more institution in connection with the family, and that is the system of pawning. Such a pawn ("Ahuba") could be redeemed, and no time-limit was ever placed on the redemption. If the pawn died, the pledgee had to notify the head of the pawn's family at once; the pledgee had no right to bury him, but had to leave the body, covered with a cloth, on an erection of four forked sticks covered with other sticks, immediately over an open grave, until the head came to perform the custom;-the erection was to keep away 
all beasts of prey, and the grave was dug so that the remains might bury themselves, if the head did not come before the sticks decayed. In some parts when a pawn died, the redemption money had to be repaid at his funeral custom; this was the case in Denkera; in Fanti Yankumase the family had the choice between paying, after a deduction had been made, or replacing the pawn by another member; this choice seems to have been the more usual.

The pawn worked for the pledgee so long as he or she remained unredeemed; he tilled the soil, or did other household work, like any domestic slave, with the important distinction that the pawn remained a member of the pledger's family, and could be redeemed; according to the general opinion, his lot was not so bad as that of a slave, and although in some cases it meant a state of perpetual bondage, I prefer to believe he was invariably redeemed. He (or she) might also be given a sum of money to trade with, and was allowed to keep half the profits. With these he might eventually redeem himself, which a slave could not. I could not confirm this at Cape Coast, but it is so in Denkera and Fanti Yankumase. In Wassaw they have a variety of selfpledging, chiefly for debts, where the pawn borrows money, and works two or three days a week in lieu of interest; this sounds plàusible, but is in reality an exorbitant rate of interest, continuing until the principal is paid; he is supposed to work the rest of the week for himself, but this is very often abused, as he is set tasks which may occupy the whole of the week, and his lot then becomes far worse than that of a slave. Sometimes, when redemption became hopeless, the right was foreclosed, on payment by the pledgee of a further advance, and the pawn then, only, became merged in the family of the pledgee as a slave. This was, however, very rare, and in Fanti Yankumase, for instance, was never allowed.

In the case of a female pawn, the pledgee could not use her as a concubine, and if he had connection with her, the debt at once became extinguished, and she was free to return home. This was modified in Fanti Yankumase, where only the interest on the debt was remitted; even this was a suffi- 
cient deterrent, as the usual rate of interest amongst the natives is 50 per cent., which, in some parts, is charged monthly!

A man could chastise a sister's child and sell or pawn him or her for his own debts, as such child was his heir-at-law; he could not in any circumstances do so to his own children, as they were members of the wife's family, nor to a brother's child, for a similar reason; he could pawn the brother himself, but only for a family debt, and only in case of there being no nephews or nieces. A younger brother could not, however, pledge an elder brother, whose duty it was to get the younger out of debt by paying it himself.

Pawning still takes place in the interior of the colony, but most of the natives now know it is against the law, and do it at their peril.

The head of a family never appears to have had the power of life and death over the members, even with the concurrence of the rest of the family; the worst fate that befell a heinous, or oft-repeated offence, was to hand the culprit over to the white man, as a steward or servant, on condition that he was not returned to the Coast; children are even now corrected by being told they will be sent to "Jaffe" (? Java) to reform them.

A few family terms are :-

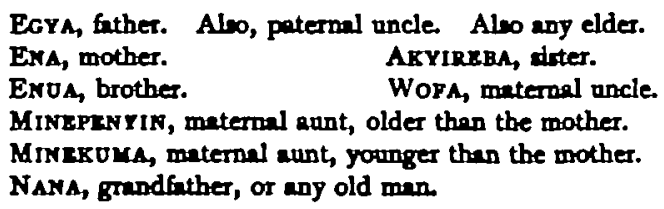

Owing to the tribal and family relations, great care has to be exercised in court to get at the real relationships. For instance, a man may tell you "so and so is my brother" where he generally means "my countryman," as all natives from the same country are brothers and sisters. I always make sure, by putting the question :-Is he born of the same mother? Then he explains. Otherwise many errors are apt to arise in the interpretation of these terms.

Infanticide never was a common practice, but is occasion- 
ally resorted to. It is said to be the custom to kill the seventh child in Apollonia, where the seventh is considered unlucky, but this is not the general practice.

I have mentioned that the first name of every native is taken from the day of the week on which he is born; the following are the days of the week, with the respective names:-

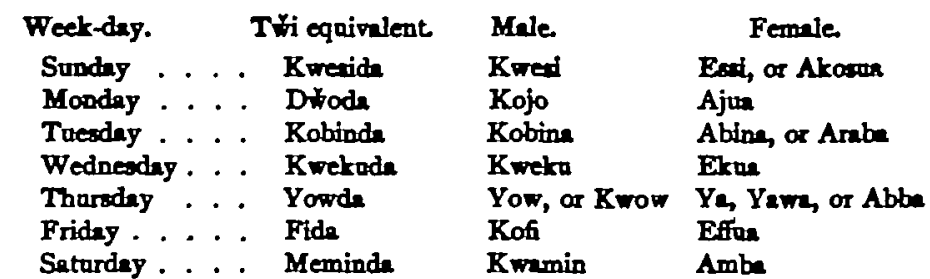

Eight days here plays its part, as eight days after the child's birth the father gives it its name. The woman is generally looked upon as convalescent for about a month after a birth, but does light household work. The child is weaned at the end of about two years, as the natives know no artificial foods. During this period the woman is supposed to live apart from her husband, as in the event of a second child being born before the first is weaned, she cannot nourish both; consequently, one, if not both, dies, and the result is often fatal to the mother as well. This quite justifies their practising polygamy. But Christianity, combined with civilisation, is affecting this practice.

The head of the family, i.e. the Penyin or elder, does all acts in the name of the family. He alone may sue or be sued in family matters. He must be consulted in every transaction connected with the family as a whole. He administers the family house and estates, allots rooms in the house for each member to live in, is asked for, and apportions plots of the family land to individuals, to build on or cultivate; without this permission, first obtained, farms or buildings made by a member are liable to be disposed of by the head. He has to be obeyed, under pain of cutting the Ekat, also called kahire, which is the ceremony of disowning a member. This had to be done before the assembled family, in the presence of the chief and his elderc. An ekar (a raund pad 
of dry leaves placed on the head for carrying loads ${ }^{1}$ ) was cut in two, the head kept one haff, and gave the disowned member the other, telling him they were henceforth parted, and his connection with the family thereupon ceased. If the disowned is a woman, even her children and their descendants are included, but owing to the strength of family ties and feeling, only the most disgraceful conduct was punished in this way.

If the penyin did not administer to the satisfaction of the members, he could be destooled without any formal notice, and a new head elected in his place. This was done by a majority of the members. All private squabbles were settled by the penyin.

The family house is the house or houses in which all the members have a right to live. If a member builds a house, and is helped in the building by any other member, even to the laying of a brick, the house at once becomes family property, and can only be attached for family, as distinct from private, debts.

I have dealt with funerals separately, and will only say here that each family buries its members in the family house, although, in some parts, the family may have a separate burial place of its own, in the form of a fetich grove, or clearing in the bush, just outside the town.

I have always been struck with the remarkably small number of old men to be found in the bush, and have always been inclined to attribute this to the fact that natives do not appreciate useless members. It is strange that they always appear to know when they are about to die, as one frequently hears a native say he is summoned home to see so and so die; when he returns, he is generally able to say that his relative died soon after he got home, and that the whole family was in

\footnotetext{
1 [In Lougande embata (Zula, inbata) the thing and the word seem to be known in all Bantu tribes, thongh the pad is quite is often made of grass. The interesting point here is the ceremanial use made of the cher. Among the $\mathrm{Zul}$. yerwe (inbote of the coantry), or, in recent times inkate yomini (inkate of the rillage, or family) is "a probol of unity and federation" (Colenso's Dictionary, p. 258). Whether ariginally an actal gnes pad or not, it is now "composed of various substances" and requires a professional "doctor" to compond it; it was tormely, when a national one existed, in the king's keeping; the inkata gaviusi is kept by the head of the clan -ED.]
} 
at the death ! Whether the old man himself knows of his approaching death or not does not seem quite clear, but it is certain all the family are told beforehand, and it is quite possible that, losing all further interest in life, he may make up his mind to die.

With regard to children, infant mortality is great, owing principally to bad nourishment, fever, and smallpox. I have already mentioned that the natives have no artificial foods, consequently, when the mother is very young, or in weak health, the child must suffer, as milk is practically unknown on the Gold Coast, except in tins from Europe, and this, when the natives can afford it, can only be had where there are stores. A weakly child, if it does not die of mal-nutrition, then becomes the more liable to fever and smallpox, which are the two commonest diseases on the Coast.

The natives are rather averse to vaccination, although the Government does its utmost to encourage it, and sends round special men to vaccinate the people, free, whenever an infected district is reported. Some of the enlightened chiefs, however, have sometimes asked for a public vaccinator to be sent into their districts, and the natives are gradually becoming more eager to report outbreaks.

Some people consider that natives, when grown up, are immune from fever; it is true that the fittest survive, but when a native adult gets fever, it is very virulent, and this disease is one of the principal causes of death.

Native women make very good mothers. They always carry their children about on their backs, seated on a pad, which forms part of every mother's attire; it is generally made of cloth, rolled up and fixed in the form of a bustle under the lower cloth, or " skirt"; the child sits on this, with its legs astride and round the mother's waist, the upper cloth being placed over the child's back, drawn under the mother's arms, and twisted in front over her bosom, the twist being turned under the cloth. This does not sound very secure, but it is, and further supports the child completely, although one frequently sees children look far from comfortable, with their heads hanging limply over their own backs, or on their shoulders, especially when very young. Negro women thus 
have their arms free, when carrying heavy head loads, pounding their corn, walking, and even dancing.

A form of discipline resorted to by native parents when sending them on errands, in order to prevent dawdling, was to spit on the ground, and to tell the child that if he did not return before the spittle dried, his navel would rot ! The navel of negro children protrudes abnormally, as primitive man does not resort to the use of elaborate bandages, \&c.; consequently the navel is a tender as well as a prominent feature of his anatomy, which subsides to a great extent as he grows older. This threat is known in Denkera, but in Fanti Yankumage a stamp of the foot indicates the parent's design. Civilisation appears to have made children wiser, and they now laugh at such a suggestion. Another tradition, which the aged Fanti deplores, is the effeminate way in which their children are now treated, as they are fed whenever they say they are hungry! In olden times if a child called for food before sunrise, he was told to first find a lizard; as this reptile does not make his appearance until after sunrise, he had to wait for dawn. I have not met this custom outside Cape Coast. The Fantis thought it made their children more hardy, but their history shows them to have been rather the reverse of brave.

ARTHUR FFOULKES, District Comimissionor, Gold Coast Colony.

Norz - The anthor sends us the following additional note to P. 400 (3): Domeatic slaves vere called Otutumafo if they eold themselves owing to poverty, Arrafo, if they did so to escape from their enemies, or when the country was devactuted by fimine; Asomfo if they became slaves in payment of a debc. In any of these caves the position was purely personel, and if they did not behave themelves, they were linble to be sold into true slavery. Slaves whose ancestors were bought generntions aga, and whose arigin has become lous, are now treated as domente slave. These are fnherited with property. The moment the become dismatified with their lot they may now go where they please, as their masters dere not claim tbem as aleves. 